\title{
Influence of Soil Fertilization Systems on Chemical Properties of the Soil
}

\author{
OANA-MARIA MUSCALU (PLESCAN) ${ }^{1,2}$, VALENTIN NEDEFF ${ }^{1,3 *}$, ION SANDU $^{4,5}$, \\ ALEXANDRA DANA CHITIMUS ${ }^{1 *}$, ELENA PARTAL ${ }^{6}$, EMILIAN MOSNEGUTU $^{1}$, \\ IOAN GABRIEL SANDU ${ }^{5,7}$, CLAUDIA TOMOZEI ${ }^{1}$ \\ ${ }^{1}$ Vasile Alecsandri University of Bacau, Department of Environmental Engineering and Mechanical Engineering, \\ 156 Calea Marasesti Str., 600115 Bacau, Romania \\ ${ }^{2}$ Romanian Waters National Administration of Siret Basin, 1 Cuza Voda Str., 600274 Bacau, Romania \\ ${ }^{3}$ Gheorghe Ionescu Sisesti, Academy of Agricultural and Forestry Sciences Bucharest, 6 Marasti Blvd., 011464 \\ Bucharest, Romania \\ ${ }^{4}$ Alexandru Ioan Cuza University of Iasi, Arheoinvest Interdisciplinary Platform, Scientific Investigation Laboratory, 11 \\ Carol I Blvd., 700506, Iasi, Romania \\ ${ }^{5}$ Romanian Inventors Forum, 3 Sf. Petru Movila Str., Bloc L11, III/3, 700089 Iasi, Romania \\ ${ }^{6}$ National Agricultural Research and Development Institute, 1 Nicolae Titulescu Str., 915200, Fundulea, Calaraşi, \\ Romania \\ ${ }^{7}$ Gheorghe Asachi Technical University of Iasi, Materials Science and Engineering Faculty, 53A D. Mangeron Blvd., \\ 700050, Iasi, Romania
}

The purpose of this research has been to determine the influence of soil fertilizations systems (fertilization with: nitrogen, phosphorous, nitrogen and phosphorous, farmyard manure) on the chemical properties (magnesium, aluminium, potassium, calcium, iron and chlorine) of the soil. The experiments have been carried out in the experimental field of National Agricultural Research and Development Institute - Fundulea, Romania, for a wheat monoculture. The lowest values of the metal content in soil (aluminium) have been recorded for wheat experimental variant fertilized with azote and phosphorous N90P75 (154.8 $\mathrm{mg} / \mathrm{kg} \mathrm{d.m}$.).Chlorine have the highest content in soil $(31.02 \mathrm{mg} / 100 \mathrm{~g}$ soil, $15-30 \mathrm{~cm}$ working depth, parcel fertilized with azote $90 \mathrm{~kg}$ N/ha) in comparation with the other chemical properties of the soil (content of magnesium, aluminium, potassium, calcium and iron).

Keywords: magnesium, aluminium, potassium, calcium, iron, chlorine, farmyard manure, wheat, monoculture

A fertilizer can be a natural or synthetic product, of a mineral and/or organic nature, simple or complex, which is applied in liquid, semi-fluid or solid form to the soil, to the surface, or foliar for the purpose of increasing soil fertility and ensuring development and normal plant growth [1-11].

Mineral fertilizers with nitrogen have a high solubility and have the quality of being able to provide almost all the necessary nutrients to the plants in a form that allows their direct and easy absorption. Another important advantage of mineral chemical fertilizers is that they allow their association and application with organic or green fertilizers [1222].

Mineral fertilizers with phosphorus have much lower solubility (10-20\% in the first year of application in the case of phosphorus and $30-40 \%$ for potassium), accumulating in the colloidal mineral formations of the soil, then being blocked in the form of heavy phosphates soluble in calcium, magnesium, iron and aluminium [12, 16, 19, 21, 23-29 ].

Animal production is developed in individual farms and in large livestock farms. An important consequence is the accumulation in large quantities of the residual organic materials of solid, liquid and semi-liquid consistency. Normally these residues, with the value of organic fertilizers, are used to fertilize agricultural land [12, 16, 28-38].

The purpose of this research has been to determine the in2fluence of soil fertilizations systems on the chemical properties (magnesium, aluminium, potassium, calcium, iron and chlorine).

\section{Experimental part}

When choosing the sampling point in order to determine the heavy metal content and physical properties of the soil, the research team took into account the topo-pedological base of the agrochemical cropping plots, updated with all necessary elements to identify and locate the plots $[12,28,29]$.

email: vnedeff@ub.ro; dana.chitimus@ub.ro 
The study has been carried out in the experimental field of National Agricultural Research and Development Institute - Fundulea, Romania, for a wheat monoculture. The researches at INCDA have been carried out following a two-factor experience, stationary and multiannual, mounted in 1968 and up to date, with reference to emphasizing the differentiation of soil's properties as an effect of fertilization sequence, i.e. [12, 28, 29]:

- azote $(90 \mathrm{~kg} \cdot \mathrm{N} / \mathrm{ha}$ active matter - active matter);

- phosphorous $(75 \mathrm{~kg} \cdot \mathrm{P} / \mathrm{ha}$ active matter $)$;

- azote and phosphorous (N90P75 kg/ha active matter);

- farmyard manure.

The experimental variants carried out at INCDA have been of the following type (Table 1) [28]:

- wheat monoculture (Factor a): $a_{1}$.

Table 1

SOIL CROP-ROTATION FOR THE PERIOD 2006-2016,

\begin{tabular}{|l|l|}
\hline \multicolumn{2}{|c}{ I.E. FOR WHEAT CULTURE. } \\
\hline \multirow{2}{*}{ YEAR } & FACTOR \\
\cline { 2 - 2 } & $\mathbf{a}_{1}$ \\
\hline $2006 \div 2017$ & wheat \\
\hline
\end{tabular}

- fertilization with (Factor b):

-unfertilized: $b_{1}$ (NOP0 kg/ha active matter);

-azote $-90 \mathrm{~kg} \mathrm{~N} / \mathrm{ha}$ active matter: $\mathrm{b}_{2}$;

-phosphorous $-75 \mathrm{~kg} \cdot \mathrm{P} / \mathrm{ha}$ active matter: $\mathrm{b}_{3}$;

-azote and phosphorous - N90P75 kg/ha active matter: $\mathrm{b}_{4}$;

-farmyard manure: $b_{5}$.

The soil samples have been taken on two depths [12, 28, 29]:

- 0 - $15 \mathrm{~cm}$;

$-15-30 \mathrm{~cm}$.

The soil samples have been taken in 2016 and 2017. All soil samples have been collected as a composite form each parcel after wheat harvesting.

Experiments have been carried out for the content of magnesium, aluminium, potassium, calcium, iron and chlorine in the soil.

Figure 1 shows soil sampling method used to determine the soil magnesium, aluminium potassium, calcium and iron content [39].

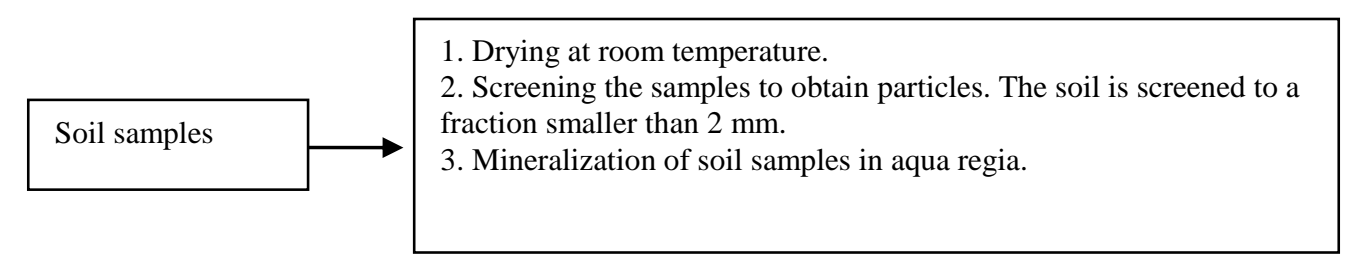

Fig. 1. Soil samples preparation methods to determine magnesium, aluminium potassium, calcium and iron content through atomic absorption spectrometry [39]

The metal content in the soil samples has been determined by using atomic absorption spectrometer (AAS), ZEENIT AAS version [39].

The chlorides content in the soil samples has been determined through titrimetric methods [40]:

- for the chlorides content we use an aqueous extract, treated according to figure 2 .

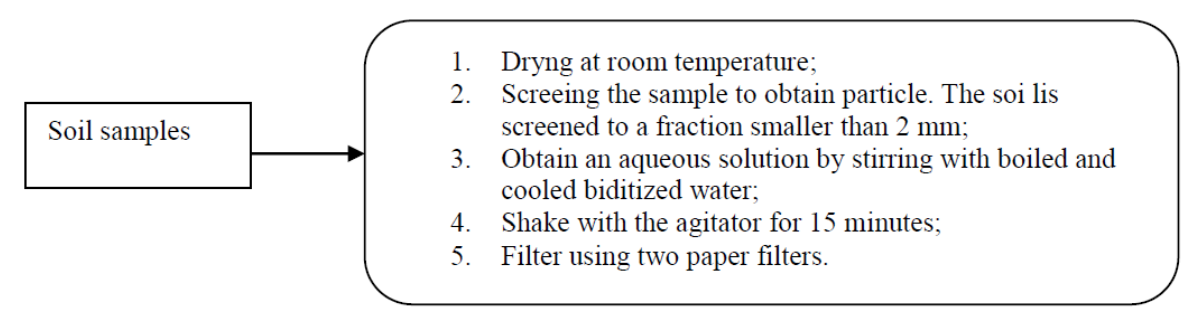

Fig. 2. Soil samples preparation methods to determine chlorides content [40]. 


\section{Results and discussions}

Table 2 show the experimentally determined values for the soil samples taken on the unfertilized wheat parcel (control sample), for magnesium, aluminium, potassium, calcium, iron and chlorine.

Table 2

EXPERIMENTALLY DETERMINED VALUES FOR THE EIGHT METALS IN THE UNFERTILIZED SOIL PARCEL (CONTROL SAMPLE)

\begin{tabular}{|c|c|c|c|c|c|c|}
\hline \multirow{2}{*}{$\begin{array}{c}\text { Depth } \\
{[\mathrm{cm}]}\end{array}$} & $\mathrm{Mg}$ & $\mathbf{A l}$ & $\mathbf{K}$ & $\mathbf{C a}$ & $\mathbf{F e}$ & \multirow{2}{*}{ 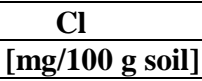 } \\
\hline & \multicolumn{5}{|c|}{ [mg/kg d.m.] } & \\
\hline $0-15$ & 587 & 1264 & 533.5 & 3752 & 300.1 & 13.29 \\
\hline $30^{15-}$ & $.5^{626}$ & 2406 & 686.8 & 8530 & 243.6 & 1.6 \\
\hline
\end{tabular}

The magnesium content (sample from year 2016) value (Fig. 3) registered in the azote fertilized parcel (90 $\mathrm{kg} \cdot \mathrm{N} / \mathrm{ha}$ ) was $102.38 \%$ higher than the value registered in the unfertilized soil parcel for the $0-15 \mathrm{~cm}$ depth, respectively by $107.34 \%$ higher than the control sample for the $15-30 \mathrm{~cm}$ depth.

For the sample from year 2017, the magnesium content registered in the azote fertilized parcel $(90 \mathrm{~kg} \cdot \mathrm{N} / \mathrm{ha}) \mathrm{was}$ $8.58 \%$ lower than the value registered in the unfertilized soil parcel for the $0-15 \mathrm{~cm}$ depth, respectively by $30.19 \%$ lower than the control sample for the $15-30 \mathrm{~cm}$ depth.

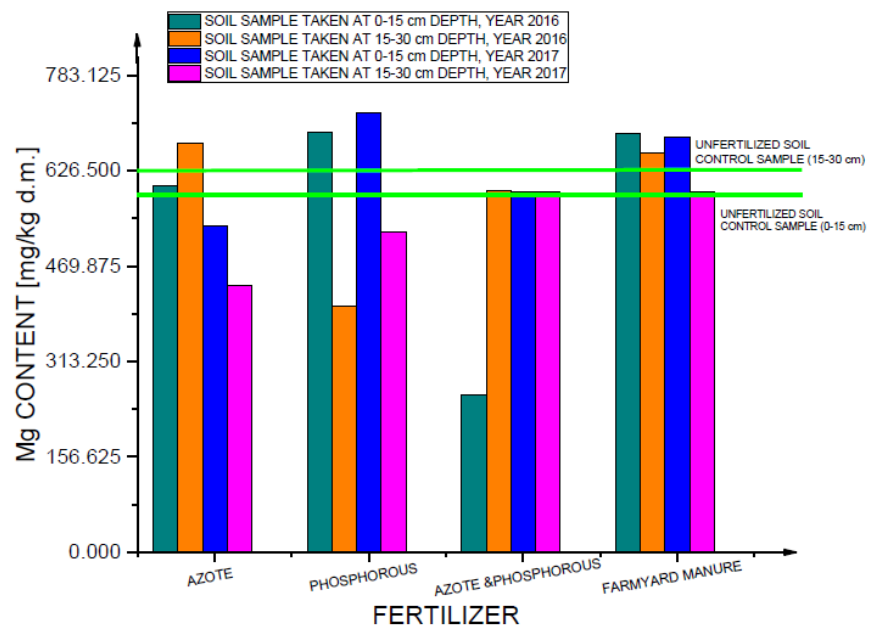

Fig. 3. Magnesium content in soil parcels fertilized with azote, phosphorous, azote and phosphorous, farmyard manure, for the $0-15 \mathrm{~cm}$ and $15-30 \mathrm{~cm}$ depths (years 2016 and 2017

In the case of the phosphorous fertilized parcel ( $75 \mathrm{~kg} \cdot \mathrm{P} / \mathrm{ha})$ the soil magnesium content was:

-year 2016: $117.46 \%$ higher than the value registered on the unfertilized soil parcel for the $0-15 \mathrm{~cm}$ depth, respectively $35.4 \%$ lower for the $15-30 \mathrm{~cm}$ depth than the control sample;

- year 2017: $122.99 \%$ higher than the value registered on the unfertilized soil parcel for the 0-15 cm depth, respectively $16.2 \%$ lower for the $15-30 \mathrm{~cm}$ depth than the control sample.

The magnesium content for the experimental wheat variants - fertilized with azote and phosphorous N90P75 kg/ha $\left(a_{1} b_{4}\right)$ and wheat - fertilized with farmyard manure $\left(a_{1} b_{5}\right)$ was:

- wheat - fertilization with azote and phosphorous N90P75 kg/ha $\left(\mathrm{a}_{1} \mathrm{~b}_{4}\right)$ - year 2016 :

- 0-15 cm: $44 \%$ of the soil control sample value;

- 15-30 cm: 101.19\% higher the valued registered in the soil control sample value;

- wheat - fertilization with farmyard manure $\left(a_{1} b_{5}\right)$ - year 2016:

- $0-15 \mathrm{~cm}: 117.2 \%$ higher than the valued registered in the soil sample with no fertilization sequence;

- 15-30 cm: $111.58 \%$ higher than the valued registered in the soil sample with no fertilization sequence.

- wheat - fertilization with azote and phosphorous N90P75 kg/ha $\left(a_{1} b_{4}\right)$ - year 2017 :

- $0-15 \mathrm{~cm}$ : $100.68 \%$ higher than the valued registered in the soil control sample value;

- 15-30 cm: $100.85 \%$ higher than the valued registered in the soil control sample value;

- wheat - fertilization with farmyard manure $\left(a_{1} b_{5}\right)$ - year 2017:

- $0-15 \mathrm{~cm}: 108.85 \%$ higher than the valued registered in the soil sample with no fertilization sequence;

- 15-30 cm: $94.49 \%$ of the soil control sample value.

The aluminium content (sample from year 2016) value (Fig. 4) on the azote fertilized parcel was $75.8 \%$ lower than the control sample value for the $0-15 \mathrm{~cm}$ depth. For the $15-30 \mathrm{~cm}$ depth the aluminium content was $14.95 \%$ of the control sample value. 
For the sample from year 2017, the aluminium content registered in the azote fertilized parcel $(90 \mathrm{~kg} \mathrm{~N} / \mathrm{ha})$ was $83.75 \%$ lower than the value registered in the unfertilized soil parcel for the $0-15 \mathrm{~cm}$ depth, respectively by $89.38 \%$ lower than the control sample for the $15-30 \mathrm{~cm}$ depth.

For the soil parcel fertilized with $75 \mathrm{~kg} \cdot \mathrm{P} / \mathrm{ha}\left(\mathrm{b}_{3}\right)$ factor, the aluminium content (sample from 2016) was $78.86 \%$ lower than the control sample value, for the $0-15 \mathrm{~cm}$ depth, respectively $86.38 \%$ lower than the control sample value for the $15-30 \mathrm{~cm}$ depth.

The aluminium content (sample from year 2017) value (Fig. 4) on phosphorous fertilized parcel was $74.21 \%$ lower than the control sample value for the $0-15 \mathrm{~cm}$ depth. For the $15-30 \mathrm{~cm}$ depth the aluminium content was $12.88 \%$ of the control sample value.

The aluminium content for the experimental wheat variants - fertilized with azote and phosphorous N90P75 $\mathrm{kg} / \mathrm{ha}$ $\left(a_{1} b_{4}\right)$ and wheat - fertilized with farmyard manure $\left(a_{1} b_{5}\right)$ was:

- wheat - fertilization with azote and phosphorous N90P75 kg/ha $\left(a_{1} b_{4}\right)$-year 2016:

- 0-15 cm: $10.07 \%$ of the soil control sample value;

- $15-30 \mathrm{~cm}: 6.43 \%$ of the soil control sample value;

- wheat - fertilization with farmyard manure $\left(a_{1} b_{5}\right)$ - year 2016:

- $0-15 \mathrm{~cm}: 73.84 \%$ lower than the valued registered in the soil sample with no fertilization sequence;

- 15-30 cm: $94.91 \%$ lower than the valued registered in the soil sample with no fertilization sequence.

- wheat - fertilization with azote and phosphorous N90P75 kg/ha $\left(a_{1} b_{4}\right)$ - year 2017:

- $0-15 \mathrm{~cm}: 70.17 \%$ lower than the valued registered in the soil control sample value;

- 15-30 cm: $94.91 \%$ lower than the valued registered in the soil control sample value;

- wheat - fertilization with farmyard manure $\left(a_{1} b_{5}\right)$ - year 2017:

- 0-15 cm: 74.21\% lower than the valued registered in the soil sample with no fertilization sequence;

- $15-30 \mathrm{~cm}: 88.17 \%$ lower than the valued registered in the soil sample with no fertilization sequence.

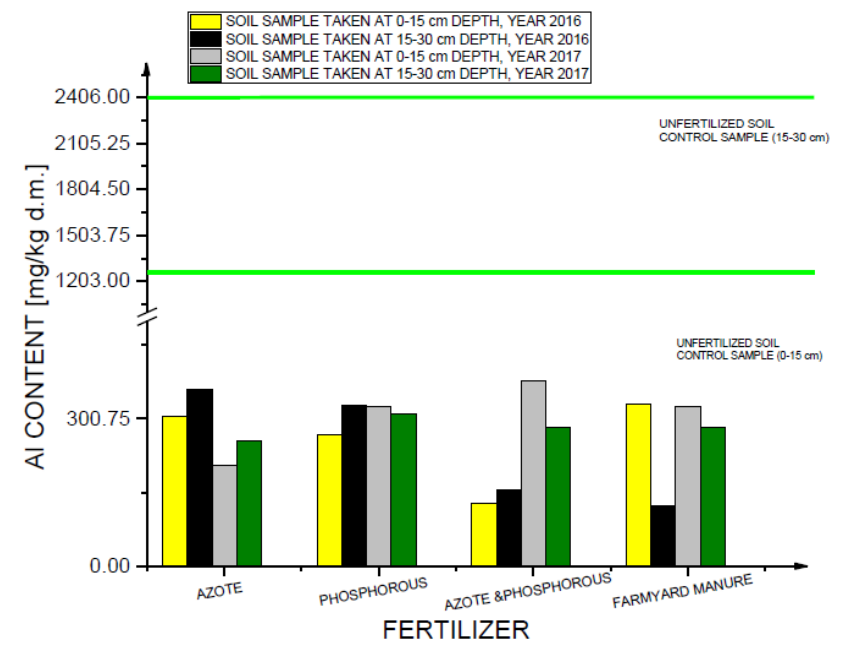

Fig. 4. Aluminium content on soil parcels fertilized with azote, phosphorous, azote and phosphorous, farmyard manure for the $0-15 \mathrm{~cm}$ and $15-30 \mathrm{~cm}$ depths (years 2016 and 2017)

The potassium content (sample from year 2016) value (Fig. 5) registered for the soil parcel fertilized with azote was $1.59 \%$ lower than the value registered for the unfertilized soil parcel for the $0-15 \mathrm{~cm}$ depth, respectively $5.94 \%$ lower than the control sample, for the $15-30 \mathrm{~cm}$ depth.

For the sample from year 2017, the potassium content registered in the azote fertilized parcel (90 kg N/ha) was $113.3 \%$ higher than the value registered in the unfertilized soil parcel for the $0-15 \mathrm{~cm}$ depth, respectively by $13.96 \%$ lower than the control sample for the $15-30 \mathrm{~cm}$ depth.

In the case of the phosphorous fertilized parcel ( $75 \mathrm{~kg} \cdot \mathrm{P} / \mathrm{ha})$ the soil potassium content was:

- year 2016: 53.53\% lower than the value registered on the unfertilized soil parcel for the 0-15 $\mathrm{cm}$ depth, respectively $79.64 \%$ lower for the $15-30 \mathrm{~cm}$ depth than the control sample;

- year 2017: $237.11 \%$ higher than the value registered on the unfertilized soil parcel for the 0-15 cm depth, respectively $13.38 \%$ lower for the $15-30 \mathrm{~cm}$ depth than the control sample.

The potassium content for the experimental wheat variant - fertilized with azote and phosphorous N90P75 kg/ha $\left(a_{1} b_{4}\right)$ was:

- wheat - fertilization with azote and phosphorous N90P75 kg/ha $\left(a_{1} b_{4}\right)$ - year 2016:

- $0-15 \mathrm{~cm}: 181.86 \%$ higher than the valued registered in the soil control sample value;

- $15-30 \mathrm{~cm}: 89.95 \%$ of the soil control sample value; 
- wheat - fertilization with azote and phosphorous N90P75 kg/ha $\left(a_{1} b_{4}\right)$ - year 2017:

- 0-15 cm: $187.12 \%$ higher than the valued registered in the soil control sample value;

- 15-30 cm: $12.74 \%$ lower than the valued registered in the soil control sample value;

The potassium content (sample from year 2016) for the experimental wheat variants - fertilized with farmyard manure $\left(\mathrm{b}_{5}\right)$ was:

$-0-15 \mathrm{~cm}: 210.94 \%$ higher than the valued registered in the soil control sample value;

- 15-30 cm: $134.4 \%$ higher than the valued registered in the soil control sample value.

For the soil parcel fertilized with farmyard manure $\left(b_{5}\right)$ the potassium content (sample from year 2017) was $234.46 \%$ higher than the control sample value, for the $0-15 \mathrm{~cm}$ depth, respectively $12.74 \%$ lower than the control sample, for the $15-30 \mathrm{~cm}$ depth.

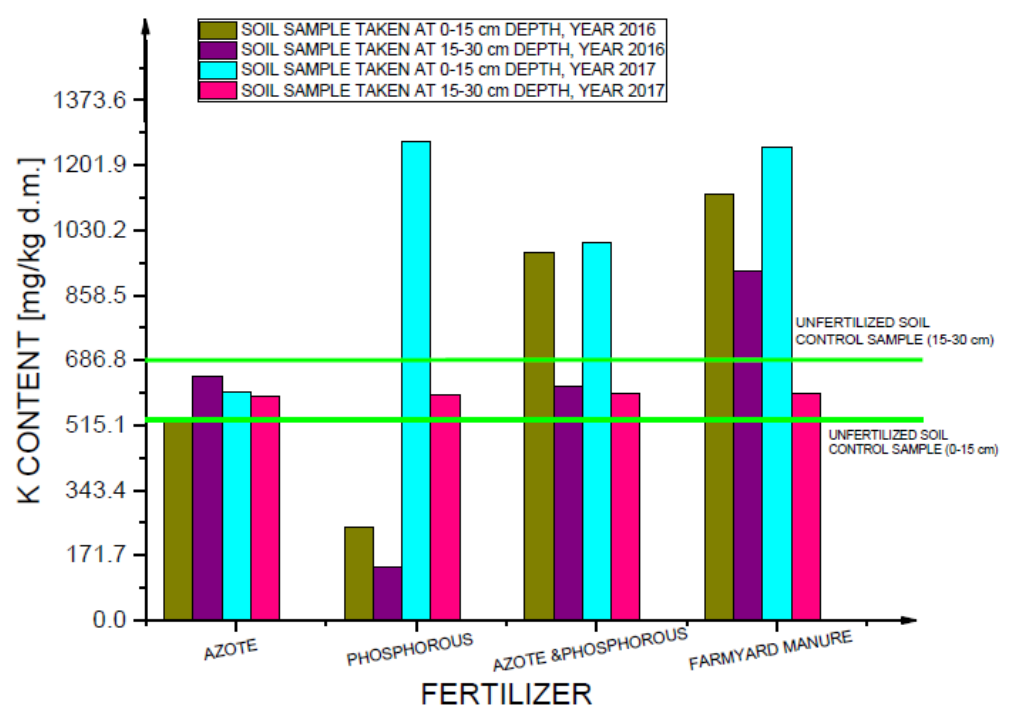

Fig. 5. Potassium content on soil parcels fertilized with azote, phosphorous, azote and phosphorous, farmyard manure for the $0-15 \mathrm{~cm}$ and $15-30 \mathrm{~cm}$ depths (years 2016 and 2017)

Calcium content (Fig. 6) for the analysed experimental variants was:

- wheat - fertilization with azote $-90 \mathrm{~kg} \cdot \mathrm{N} / \mathrm{ha}\left(\mathrm{a}_{1} \mathrm{~b}_{2}\right)$ - year 2016 :

- $0-15 \mathrm{~cm}: 38.37 \%$ lower than the valued registered in the soil sample with no fertilization sequence;

- $15-30 \mathrm{~cm}: 30.01 \%$ of the soil control sample value;

- wheat - fertilization with azote $-90 \mathrm{~kg} \cdot \mathrm{N} / \mathrm{ha}\left(\mathrm{a}_{1} \mathrm{~b}_{2}\right)$ - year 2017 :

- $0-15 \mathrm{~cm}: 106.21 \%$ higher than the valued registered in the soil sample with no fertilization sequence;

- $15-30 \mathrm{~cm}: 48.35 \%$ of the soil control sample value;

- wheat - fertilization with phosphorous $-75 \mathrm{~kg} \cdot \mathrm{P} / \mathrm{ha}\left(\mathrm{a}_{1} \mathrm{~b}_{3}\right)$ - year 2016 :

- 0-15 cm: cu 102.61\% higher than the valued registered in the soil sample with no fertilization sequence;

- 15-30 cm: cu $45.55 \%$ of the soil control sample value.

- wheat - fertilization with phosphorous $-75 \mathrm{~kg} \cdot \mathrm{P} / \mathrm{ha}\left(\mathrm{a}_{1} \mathrm{~b}_{3}\right)$-year 2017 :

- $0-15 \mathrm{~cm}$ : cu $6.21 \%$ lower than the valued registered in the soil sample with no fertilization sequence;

- 15-30 cm: cu 66.03\% lower than the valued registered in the soil sample with no fertilization sequence.

- wheat - fertilization with azote and phosphorous - N90P75 kg/ha $\left(a_{1} b_{4}\right)$ - year 2016:

- 0-15 cm: $71.69 \%$ of the soil control sample value;

$\bullet 15-30 \mathrm{~cm}$ : $23.44 \%$ of the soil control sample value;

- wheat - fertilization with azote and phosphorous - N90P75 kg/ha $\left(a_{1} b_{4}\right)$ - year 2017:

- $0-15 \mathrm{~cm}: 78.35 \%$ of the soil control sample value;

$\bullet 15-30 \mathrm{~cm}$ : $43.86 \%$ of the soil control sample value;

- wheat - fertilization with farmyard manure $\left(a_{1} b_{5}\right)$ - year 2016:

- $0-15 \mathrm{~cm}$ : cu $10.92 \%$ lower than the valued registered in the soil sample with no fertilization sequence;

- 15-30 cm: cu 66.52\% lower than the valued registered in the soil sample with no fertilization sequence;

- wheat - fertilization with farmyard manure $\left(a_{1} b_{5}\right)$ - year 2017:

- 0-15 cm: cu 1.19\% lower than the valued registered in the soil sample with no fertilization sequence;

- 15-30 cm: cu 57.30\% lower than the valued registered in the soil sample with no fertilization sequence. 


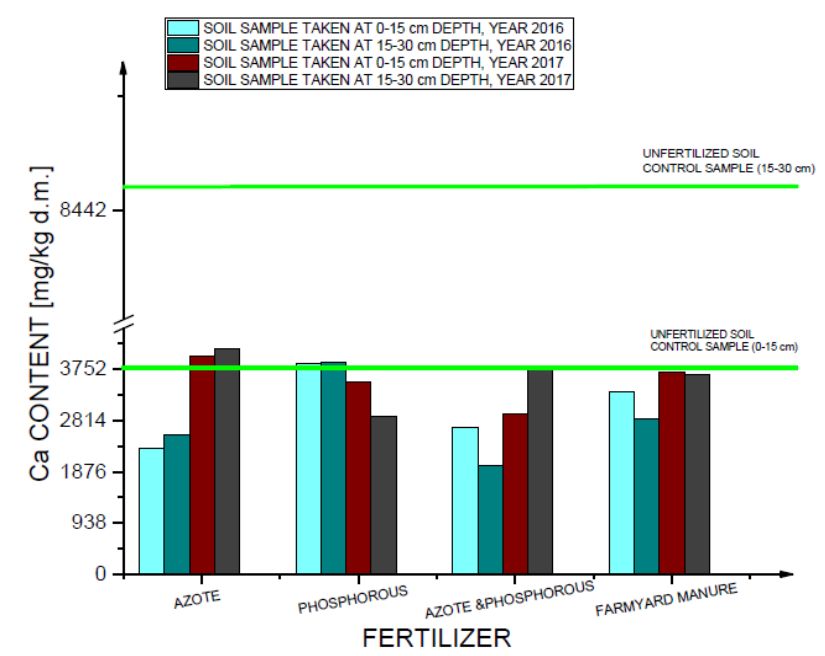

Fig. 6. Calcium content on soil parcels fertilized with azote, phosphorous, azote and phosphorous, farmyard manure for the $0-15 \mathrm{~cm}$ and 15-30 cm depths (years 2016 and 2017)

Iron content value (Fig. 7) registered for the soil parcel fertilized with azote (sample from year 2016) was 112.12\% higher than the control sample value for the $0-15 \mathrm{~cm}$ depth. For the $15-30 \mathrm{~cm}$ depth the iron content was $167.15 \%$ higher than the control sample value.

For the sample from year 2017, the iron content registered in the azote fertilized parcel (90 kg. N/ha) was $116.49 \%$ higher than the value registered in the unfertilized soil parcel for the $0-15 \mathrm{~cm}$ depth, respectively by $162.47 \%$ higher than the control sample for the $15-30 \mathrm{~cm}$ depth.

For the soil parcel fertilized with phosphorous $\left(b_{3}\right)$, the iron content (sample from year 2016) was $165.21 \%$ higher than the control sample value for the $0-15 \mathrm{~cm}$ depth, respectively $114.81 \%$ higher than the control sample, for the 15 $30 \mathrm{~cm}$ depth.

The iron content (sample from year 2017) value (Fig. 7) on phosphorous fertilized parcel was $125.45 \%$ higher than the control sample value for the $0-15 \mathrm{~cm}$ depth. For the $15-30 \mathrm{~cm}$ depth the iron content was $93.14 \%$ of the control sample value.

The iron content for the experimental variants wheat - fertilization with azote and phosphorous N90P75 kg/ha $\left(a_{1} b_{4}\right)$ and wheat - fertilization with farmyard manure $\left(a_{1} b_{5}\right)$ was:

- wheat - fertilization with azote and phosphorous - N90P75 kg/ha $\left(a_{1} b_{4}\right)$ - year 2016 :

- 0-15 cm: $64.64 \%$ of the soil control sample value;

-15-30 cm: $167.81 \%$ higher than the valued registered in the soil sample with no fertilization sequence;

- wheat - fertilization with azote and phosphorous - N90P75 kg/ha $\left(\mathrm{a}_{1} \mathrm{~b}_{4}\right)$ - year 2017 :

- 0-15 cm: 109.16\% higher than the valued registered in the soil sample with no fertilization sequence;

-15-30 cm: $133.16 \%$ higher than the valued registered in the soil sample with no fertilization sequence;

- wheat - fertilization with farmyard manure $\left(a_{1} b_{5}\right)$ - year 2016:

- 0-15 cm: cu $169.34 \%$ higher than the valued registered in the soil sample with no fertilization sequence;

- 15-30 cm: cu 189.77\% lower than the valued registered in the soil sample with no fertilization sequence;

- wheat - fertilization with farmyard manure $\left(a_{1} b_{5}\right)$ - year 2017:

- $0-15 \mathrm{~cm}$ : cu $118.46 \%$ higher than the valued registered in the soil sample with no fertilization sequence;

- 15-30 cm: cu 133.16\% higher than the valued registered in the soil sample with no fertilization sequence.

The chlorine content (Fig. 8) registered for the soil parcel fertilized with azote (sample from year 2016) was (90 $\mathrm{kg} \cdot \mathrm{N} / \mathrm{ha}$ ) was $166.66 \%$ higher than the value registered for the unfertilized soil parcel for the $0-15 \mathrm{~cm}$ depth, respectively $1938.75 \%$ higher than the control sample, for the $15-30 \mathrm{~cm}$ depth.

For the sample from year 2017, the chlorine content registered in the azote fertilized parcel (90 kg. N/ha) was $60.12 \%$ lower than the value registered in the unfertilized soil parcel for the $0-15 \mathrm{~cm}$ depth, respectively by $316.67 \%$ higher than the control sample for the $15-30 \mathrm{~cm}$ depth.

In the case of the phosphorous fertilized parcel $(75 \mathrm{~kg} \cdot \mathrm{P} / \mathrm{ha})$ the soil chlorine content was:

- year 2016: $123.77 \%$ higher than the value registered on the unfertilized soil parcel for the $0-15 \mathrm{~cm}$ depth, respectively $19.11 \%$ lower for the $15-30 \mathrm{~cm}$ depth than the control sample;

- year 2017: 195.63\% higher than the value registered on the unfertilized soil parcel for the 0-15 cm depth, respectively $650 \%$ higher for the $15-30 \mathrm{~cm}$ depth than the control sample. 
For the soil parcel fertilized with azote and phosphorous $\left(b_{4}\right)$, the chlorine content (sample from year 2016) was $112.49 \%$ higher than the value registered on the unfertilized soil, for the $0-15 \mathrm{~cm}$ depth, respectively $948.75 \%$ higher than the value registered on the unfertilized soil, for the $15-30 \mathrm{~cm}$ depth.

The chlorine content (sample from year 2017) value (Fig. 8) on phosphorous fertilized parcel was $64.29 \%$ lower than the control sample value for the 0-15 cm depth. For the $15-30 \mathrm{~cm}$ depth the chlorine content was $225 \%$ higher than the control sample value.

The chlorine content for the experimental variant wheat - fertilization with farmyard manure $\left(a_{1} b_{5}\right)$ was:

- wheat - fertilization with farmyard manure $\left(a_{1} b_{5}\right)$ - year 2016:

- $0-15 \mathrm{~cm}$ : cu $18.73 \%$ lower than the valued registered in the soil sample with no fertilization sequence;

- 15-30 cm: cu 870\% higher than the valued registered in the soil sample with no fertilization sequence;

- wheat - fertilization with farmyard manure $\left(a_{1} b_{5}\right)$ - year 2017:

- 0-15 cm: cu 203.16\% higher than the valued registered in the soil sample with no fertilization sequence;

- 15-30 cm: cu 239.75\% higher than the valued registered in the soil sample with no fertilization sequence.

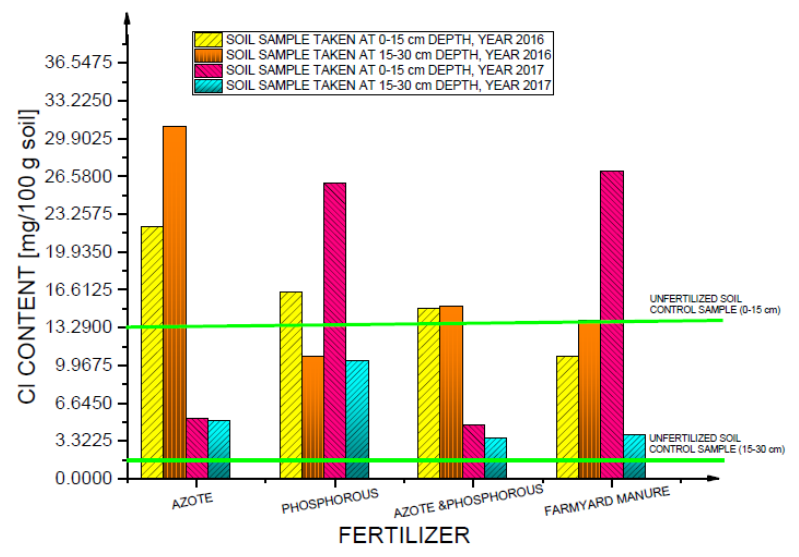

Fig. 8. Chlorine content on soil parcels fertilized with azote, phosphorous, azote and phosphorous, farmyard manure for the $0-15 \mathrm{~cm}$ and $15-30 \mathrm{~cm}$ depths (years 2016 and 2017)

\section{Conclusions}

The research carried out in 2016 and 2017 with regard to the influence of fertilizations systems (fertilization with: nitrogen, phosphorous, nitrogen and phosphorous, farmyard manure) on the chemical properties (magnesium, aluminium, potassium, calcium, iron and chlorine) of the soil emphasized the following aspects:

- the magnesium content for the experimental wheat variants - fertilized with azote and phosphorous N90P75 $\mathrm{kg} / \mathrm{ha}\left(\mathrm{a}_{1} \mathrm{~b}_{4}\right)$ was the lower value registered for the level $0-15 \mathrm{~cm}-44 \%$ of the soil control sample value (sample from year 2016);

- the magnesium content for the experimental wheat variants - fertilized with phosphorous $(75 \mathrm{~kg} \cdot \mathrm{P} / \mathrm{ha})$ the soil magnesium content was the higher value registered for the level 0-15 cm:122.99\% higher than the value registered on the unfertilized soil parcel (sample from year 2017);

- in case of aluminium the value registered in the soil, was under soil sample value for the both years (the maximal value registered was for the level $0-15 \mathrm{~cm}, 26.16 \%$ of the soil control sample value - year 2016 and the minimal value registered was for the level $15-30 \mathrm{~cm}, 6.43 \%$ of the soil control sample value - year 2016), for the experimental wheat variants - fertilized with azote and phosphorous N90P75 kg/ha $\left(\mathrm{a}_{1} \mathrm{~b}_{4}\right)$;

- in case of calcium the value registered in the soil for the level $15-30 \mathrm{~cm}$, was under soil sample value, for all the fertilizations systems applied

- the potassium content for the experimental wheat variants - fertilized with phosphorous $(75 \mathrm{~kg} \cdot \mathrm{P} / \mathrm{ha})$ was the lower value registered for the level $15-30 \mathrm{~cm}, 139.9 \mathrm{mg} / \mathrm{kg}$ dry matter (sample from year 2016);

- the magnesium content for the experimental wheat variants - fertilized with phosphorous $(75 \mathrm{~kg} \cdot \mathrm{P} / \mathrm{ha})$ the soil magnesium content was the higher value registered for the level $0-15 \mathrm{~cm}: 1265 \mathrm{mg} / \mathrm{kg}$ dry matter (sample from year 2017);

- in case of iron the value registered in the soil for the both level analysed, was over soil sample value, for all the fertilizations systems applied making exception the next levels:

- 0-15 cm: $64.64 \%$ of the soil control sample value (fertilization with azote and phosphorous N90P75 kg/ha, sample from year 2016);

- 15-30 cm: $93.14 \%$ of the control sample value (fertilization with phosphorous $75 \mathrm{~kg} \cdot \mathrm{P} / \mathrm{ha}$, sample from year 2017); 
- in case of chlorine the value registered in the soil for the level $15-30 \mathrm{~cm}$, was over soil sample value, for all the fertilizations systems applied.

Soil's metal contents variations are mainly due to the applied fertilizers sequence (azote, phosphorous, azote and phosphorous, farmyard manure), to wheat capacity to stabilize in soil, as well as to climatic conditions in 2016 and 2017.

\section{References}

1.UZOMA, K.C., INOUE, M., ANDRY, H., FUJIMAKI, H., ZAHOOR, A., NISHIHARA, E., Soil Use and Management, 27, no. 2, 2011, p. 205.

2.YANG, R., SU, Y., WANG, T., YANG, Q., Journal of Integrative Agriculture, 15, no. 3, 2017, p. 658.

3.ARDELEANU, G., TOMOZEI, C., IRIMIA, O., PANAINTE-LEHADUS, M., 16th International Multidisciplinary Scientific GeoConference SGEM 2016, SGEM 2016 Conference Proceedings, 3, 2, 2016, p. 763.

4.IRIMIA, O., TOMOZEI, C., PANAINTE LEHĂDUŞ, M., MOSNEGUTU, E., BARSAN, N., Environmental Engineering and Management Journal, 12, no. 1, 2013, p. 35.

5.BELCIU, M.C., NEDEFF, V., CHIŢIMUŞ, A.D., RADU, C., Journal of Engineering Studies and Research, 20, no.1, 2017 , p. 23.

6.ADAMIAK, E., ADAMIAK, J., Acta Scientarum Polonorum Agricultura, 14, no. 1, 2015, p. 3.

7.CHITIMUS, D., COCHIORCA, A., NEDEFF, V., MUSCALU, O., BARSAN, N., Proceeding of the International Multidisciplinary Scientific GeoConference Surveying Geology and Mining Ecology Management, SGEM, 18, 2018, p. 671.

8.SWEDRZYŃSKA, D., MAŁECKA, I., BLECHARCZYK, A., SWĘDRZYŃSKI, A., STARZYK, J., Polish Journal of Environmental Studies, 22, no. 6, 2013, p. 1835.

9.CHITIMUS, A.D., NEDEFF, V., MOSNEGUTU, E.F., PANAINTE, M., Environmental Engineering and Management Journal, 11, no. 12, 2012, p. 2161.

10.SCHERER, H.W., METKER, D.J., WELP, G., Soil and Environment, 57, 2011, p. 513.

11.BELCIU, M.C., NEDEFF, V., CHITIMUS, A.D., BARSAN, N., RUSU, D., Journal of Engineering Studies and Research, 22, no.1, 2016, p. 15.

12.MUSCALU (PLEȘCAN), O.M., NEDEFF, V., CHITIMUS, A.D., PARTAL, E., BARSAN, N., RUSU, I.D., Rev. Chim. (Bucharest), 70, no. 2, 2019, p. 536.

13.MARIANGELA, D., FRANCESCO, M., Sustainable Agriculture, 2, 2011, p. 761.

14. BELCIU, M.C., MOŞNEGUȚU, E.F., NEDEFF, V., CHIȚIMUȘ, A.D., BARSAN, N., FIORE, S., Environmental Engineering and Management Journal, 15, no. 3, 2016, p. 2057.

15.BELAY, A., CLAASSENS, A.S., WEHNER, F.C., Biology and Fertility of Soils, 35, no. 6, 2002, p. 420.

16.CHITIMUS, A.D., Studies and researches on the influence of mechanical and physical properties of soil in self-cleaning and cleaning, PhD Thesis, Vasile Alecsandri University of Bacau, Romania, 2011.

17.CHITIMUS, A.D., NEDEFF, V., MOSNEGUTU, E., LAZAR, G., Soil Cleaning Techniques (in Romanian), Ed. Alma Mater, Bacau, 2012, p. 51 .

18.CHITIMUS, A.D., NEDEFF, V., LAZĂR, G., Journal of Engineering Studies and Research, 17, no. 4, 2011, p. 24-31.

19.BELAY, A., CLAASSENS, A.S., WEHNER, F.C., DE BEER, J.M., South African Journal of Plant and Soil, 18, no. 1, 2001, p. 1.

20.CHITIMUS, A.D., RADU, C., NEDEFF, V., MOSNEGUTU, E., BARSAN, N., Scientific Study \& Research Chemistry \& Chemical Engineering, Biotechnology, Food Industry, 17, no. 4, 2016, p. 381.

21.CHITIMUS, A.D., BARSAN, N., NEDEFF, V., MOSNEGUTU, E., MUSCALU (PLESCAN), O., 17th International Multidisciplinary Scientific GeoConference SGEM 2017, 17, no. 51, 2017, p. 859.

22.CLEMENS, S., PALMGREN, M.G., KRÄMER, U., A Plant Science, 7, 2002, p. 309.

23.GREGER, M., Uptake of nuclides by plants, Technical Report TR-04-14, Svensk Karnbranslehantering, Stockholm, 2004. https://inis.iaea.org/collection/NCLCollectionStore/_Public/35/080/35080548.pdf?r=1\&r=1).

24.RADU, C., CHITIMUS, A.D., TURCU, M., ARDELEANU, G., BELCIU M., Environmental Engineering and Management Journal, 13, no. 7, 2014, p. 1687.

25.RADU, C., NEDEFF, V., CHITIMUS, A.D., Journal of Engineering Studies and Research, 19, no. 2, 2013, p. 89.

26.SENILA, M., LEVEI, E., MICLEAN, M., SENILA, L., STEFANESCU, L., MĂRGINEAN, S., OZUNU, A., ROMAN, C., Environmental Engineering and Management Journal, 10, 2011, p. 59.

27.BHANDARI, A.L., LADHA, J.K., PATHAK, H., PADRE, A.T., DAWE, D., GUPTA, R.K., Soil Science Society of America Journal, 66, no. 1,2002 , p. 162.

28.MUSCALU (PLEȘCAN), O.M., NEDEFF, V., CHITIMUS, A.D., PARTAL, E., MOSNEGUTU, E., RUSU, I.D., Rev. Chim. (Bucharest), 69, no. 11, 2018, p. 3106.

29.MUSCALU (PLEȘCAN), O.M., NEDEFF, V., PARTAL, E., MOSNEGUTU, E., SANDU, I.G., SANDU, I., BARSAN, N., RUSU, D., Rev. Chim. (Bucharest), 70, no. 5, 2019, p. 1726.

30.GARG, S., BAHL, G.S., Bioresource Technology, 99, no. 13, 2008, p. 5773.

31.CHITIMUS, A.D., NEDEFF, V., SANDU, I., RADU, C., MOSNEGUTU, E., SANDU, I.G., BARSAN, B., Rev. Chim. (Bucharest), 70, no. 7, 2019, p. 2545.

32.CHITIMUS, A.D., NEDEFF, V., SANDU, I., RADU, C., MOSNEGUTU, E., SANDU, I.G., BARSAN, B., Rev. Chim. (Bucharest), 70, no. 8, 2019, p. 3058 .

33. SAMPAH, G.E., KOUAKOU, S.K., OI, M.J.M., NEDEFF, V., SANDU, A.V., BARSAN, N., SANDU, I., Rev. Chim. (Bucharest), 70, no. 7, 2019, p. 2579.

34.GOLDAN, E., NEDEFF, V., BARSAN, N., MOSNEGUTU, E., SANDU, A.V., PANAINTE, M., Rev. Chim. (Bucharest), 70, no. 3, 2019, p. 809. 
35.COCHIORCA, A., NEDEFF, V., BARSAN, N., MOSNEGUTU, E.F., PANAINTE-LEHADUS, M., TOMOZEI, C., Chemistry \& Chemical Engineering, Biotechnology, Food Industry, 19, no. 4, 2018, p. 455.

36.GOLDAN, E., NEDEFF, V., SANDU, I., BARSAN, N., MOSNEGUTU, E., PANAINTE, M., Rev. Chim. (Bucharest), 70, no. 6, 2019, p. 2212.

37. MISAILA, L, NEDEFF, F.M., BARSAN, N., SANDU, I.G., GROSU, L., PATRICIU, O.I., GAVRILA, L., FINARU, A.L., Rev. Chim. (Bucharest), 70, no. 6, 2019, p. 2192.

38. COCHIORCA, A., NEDEFF, V., BARSAN, N., PANAINTE-LEHADUS, M., MOSNEGUTU, E.F., Proceeding of the International Multidisciplinary Scientific GeoConference Surveying Geology and Mining Ecology Management, SGEM, vol. 18, no. 3., 2018, p. 87-94.

39.***Atomic absorption spectrometry (AAS) ZEEnit 700, Operating Manual, 2009.

40.***SR ISO 9297/2001 - Water quality - Determining the chloride content. Method Mohr

$\overline{\text { Manuscript received: } 11.12 .2019}$ 